Nat. Hazards Earth Syst. Sci., 19, 1055-1066, 2019

https://doi.org/10.5194/nhess-19-1055-2019

(c) Author(s) 2019. This work is distributed under

the Creative Commons Attribution 4.0 License.

\title{
Contrasting large fire activity in the French Mediterranean
}

\author{
Anne Ganteaume and Renaud Barbero \\ Irstea, Mediterranean Ecosystems and Risks, Aix-en-Provence, France
}

Correspondence: Anne Ganteaume (anne.ganteaume@ irstea.fr)

Received: 10 September 2018 - Discussion started: 21 September 2018

Revised: 29 March 2019 - Accepted: 11 April 2019 - Published: 16 May 2019

\begin{abstract}
In the French Mediterranean, large fires have significant socioeconomic and environmental impacts. We used a long-term georeferenced fire time series (1958-2017) to analyze both spatial and temporal distributions of large fires (LFs; $\geq 100$ ha). The region was impacted in some locations up to six times by recurrent LFs and $21 \%$ of the total area burned by LFs occurred on a surface that previously burned in the past, with potential impact on forest resilience. We found contrasting patterns between the east and the west of the study area, the former experiencing fewer LFs but of a larger extent compared to the latter, with an average time of occurrence between LFs exceeding 4000 ha $<7$ years mostly in the eastern coastal area and $>50$ years in the west. This longitudinal gradient in LF return level contrasts with what we would expect from mean fire weather conditions strongly decreasing eastwards during the fire season but is consistent with larger fuel cover in the east, highlighting the strong role of fuel continuity in fire spread. Additionally, our analysis confirms the sharp decrease in both LF frequency and burned area in the early 1990s, due to the efficiency of fire suppression and prevention reinforced at that time, thereby weakening the functional climate-fire relationship across the region.
\end{abstract}

\section{Introduction}

It is now unanimously agreed upon that large fires have the most significant socioeconomic and environmental impacts, threatening or damaging infrastructures, ecosystems and even costing human lives, especially in the expanding wildland-urban interfaces (WUIs) (Blanchi et al., 2014; Syphard and Keeley, 2015; Radeloff et al., 2018). However, the definitions of what can be considered a large fire are numerous (Shvidenko and Nilsson, 2000; Stocks et al., 2002; Barbero et al., 2015a; Stavros et al., 2014; Nagy et al., 2018;
Tedim et al., 2018), the cutoff being arbitrary or statistically assessed. Usually, large fires represent only a small proportion of the total number of fires but they typically account for the bulk of burned area in many regions throughout the world (Stocks et al., 2002; San Miguel-Ayanz et al., 2013; Stavros et al., 2014; Barbero et al., 2014, 2015a; Ganteaume and Guerra, 2018) and in fact determine the trend and interannual variability in the total burned area.

Large fires and fire severity have increased over the past several decades across parts of the globe (Pausas and Fernández-Muñoz, 2012; Dennison et al., 2014; Stephens et al., 2014), these changes being attributed to a combination of climate change (Westerling et al., 2006; Bradstock et al., 2009; Flannigan et al., 2009; Barbero et al., 2015b; Abatzoglou and Williams, 2016) and past fire suppression (McKenzie et al., 2004; Littell et al., 2009; Miller et al., 2009). However, these upward trends are not universal and some landscapes, mostly in southern Europe, have not experienced such increases in large fires and have even showed a decline since the 1990s (San Miguel-Ayanz et al., 2013; Ruffault and Mouillot, 2015; Ganteaume and Guerra, 2018), albeit conflicting signals were found across parts of Portugal and Spain (Turco et al., 2016). This overall fire reduction has been attributed to an increased effort in fire management after the large fires in the 1980s (Turco et al., 2016; Fréjaville and Curt, 2017).

In Mediterranean systems, bottom-up drivers are generally thought to play a strong role in fire activity. Indeed, ignitions are mainly due to human activities (negligence or arson) as seen in California (Syphard and Keeley, 2015; Kolden and Abatzoglou, 2018) or in southeastern France (Ganteaume and Jappiot, 2013) where very few fires are started by lightning strikes (Ganteaume et al., 2013). Likewise, fuel structure and composition control fire spread and, therefore, the location of the largest fires (Duane et al., 2015; Fernandes et 
al., 2016). The fuel structure is also subject to human activities (Moreira et al., 2011), with agricultural land abandonment or systematic fire suppression leading to the buildup of a large amount of fuels (Pausas and Fernández-Muñoz, 2012). Additionally, top-down drivers including fire weather conditions can help define areas where large fires are most likely to occur (Moritz et al., 2012; Ruffault et al., 2016) but also provide windows of opportunity for fire spread. Large fires in Mediterranean climate ecosystems are often enabled by episodes of severe fire weather of varying duration that can be generated by dry and hot winds as seen in California (Abatzoglou et al., 2013; Kolden and Abatzoglou, 2018) or by dry but cold wind as seen in southeastern France (Ruffault et al., 2016). Collectively, climatic factors alongside ignition sources, fuels, but also suppression forces are thought to influence fire spread. It is noteworthy that changes in fire suppression policy over the last few decades mentioned above have induced sharp decreases in fires, partially modifying the functional relationships linking fire to climate (Curt and Fréjavill, 2018; Syphard et al., 2017), and thus decreasing fire activity independently of the climate forcing (Hawbaker et al., 2013; Syphard et al., 2007).

We focused here on the French Mediterranean, the most fire-prone region of France, where the largest fire on record reached 11580 ha despite a highly fragmented landscape. This is also a highly populated area characterized by an extensive WUI and high network density, which are highly impacted by fire ignitions, especially in the western part (Ganteaume and Long-Fournel, 2015) with the potential for several consecutive reburns. The region includes plant communities well adapted to Mediterranean climate conditions that confer a high fire risk on this area but an increase in fire recurrence and a shortening of the period between fires were shown to impact vegetation structure, especially with the decrease in mature tree cover (Ganteaume et al. 2009), including the loss of resilience of Pinus halepensis stands (Eugenio et al., 2006). It is thus of interest to quantify reburns across the region given their detrimental impacts on ecosystems.

Additionally, little attention has been devoted to understanding the spatial distribution of large fires along a longitudinal transect. From a bottom-up perspective, fire-prone areas along the Mediterranean coast have been extensively built up in the western part of the region, thereby reducing the availability of fuel while increasing the probability of human-started fires (Ganteaume et al., 2013). From a topdown perspective, climatological annual precipitation (wind speed) is increasing (decreasing) eastwards, gradually lowering the weather-induced fire danger. How these two factors, namely fuel continuity and fire weather, modulate the occurrence of large fires is still unclear.

Previous works in the French Mediterranean were based on gridded fire data commencing from the mid-1970s (e.g., Ruffault et al., 2016; Fréjaville and Curt, 2017; Ganteaume and Guerra, 2018; Lahaye et al., 2018). Here, we used, for the first time, longer time series of georeferenced fires extending back to 1958 and sought to examine both spatial and temporal distributions of large fires across the French Mediterranean. More specifically, this paper has a threefold objective. First, we sought to identify the locations associated with large fire recurrence and quantify the spatial extent of the region with reburns. Second, we sought to establish the mean fire extent and the fire return level along a longitudinal transect spanning the French Mediterranean and identify the possible role of climate conditions and fuel continuity in shaping this longitudinal gradient. This exploratory analysis may provide some insights into a fire aspect that was overlooked in previous studies. Finally, building on previous research, we sought to re-estimate trends in large fires across the region taking advantage of a fire record spanning almost 6 decades.

\section{Material and methods}

\subsection{Study area}

The study area (total surface area of $11157 \mathrm{~km}^{2}$ ) is one of the most fire-prone regions of southeastern France in terms of fire frequency (i.e., number of fires) and burned area (Ganteaume and Jappiot, 2013; Ganteaume and Guerra, 2018). The western part is characterized by an extensive WUI where the ignitions are the most frequent (47\% of the total ignitions occurred in the WUI) (Ganteaume and Long-Fournel, 2015). Most large fires occur in summer but their cause is often unknown and when it is known, these large fires are mainly due to arson (Ganteaume and Guerra, 2018).

The two parts of the study area (Fig. 1), located on a west-east gradient of the Mediterranean, share most climate characteristics albeit annual precipitation (wind speed) increases (decreases) eastwards (Ruffault et al., 2017). These areas also differ in the structure of landscapes; forested massifs are larger in the eastern zone while the proportion of WUIs (15\% vs. $7 \%$; Ganteaume and Long-Fournel, 2015, and Ganteaume, unpublished data, respectively) and urbanization are higher in the western area (396 vs. 176 inhabitants km ${ }^{-2}$, https://www.insee.fr/fr/ statistiques/2011101?geo=DEP-13, last access: 25 February 2019; https://www.insee.fr/fr/statistiques/1405599?geo= DEP-83, last access: 25 September 2018), as well as in the main flammable fuel types, due to the nature of the bedrock (acidic soils being mainly located in the east as opposed to limestone-derived soils in the west). All these differences are hypothesized to affect fire spread and ultimately the distribution of large fires.

\subsection{Fire data}

Large fires in the French Mediterranean have already been studied in previous works using shorter time series based on the gridded regional fire database Prométhée that has recorded fires since 1973 (Fréjaville and Curt, 2015; Ruffault and Mouillot, 2017; Ruffault et al., 2018). However, 

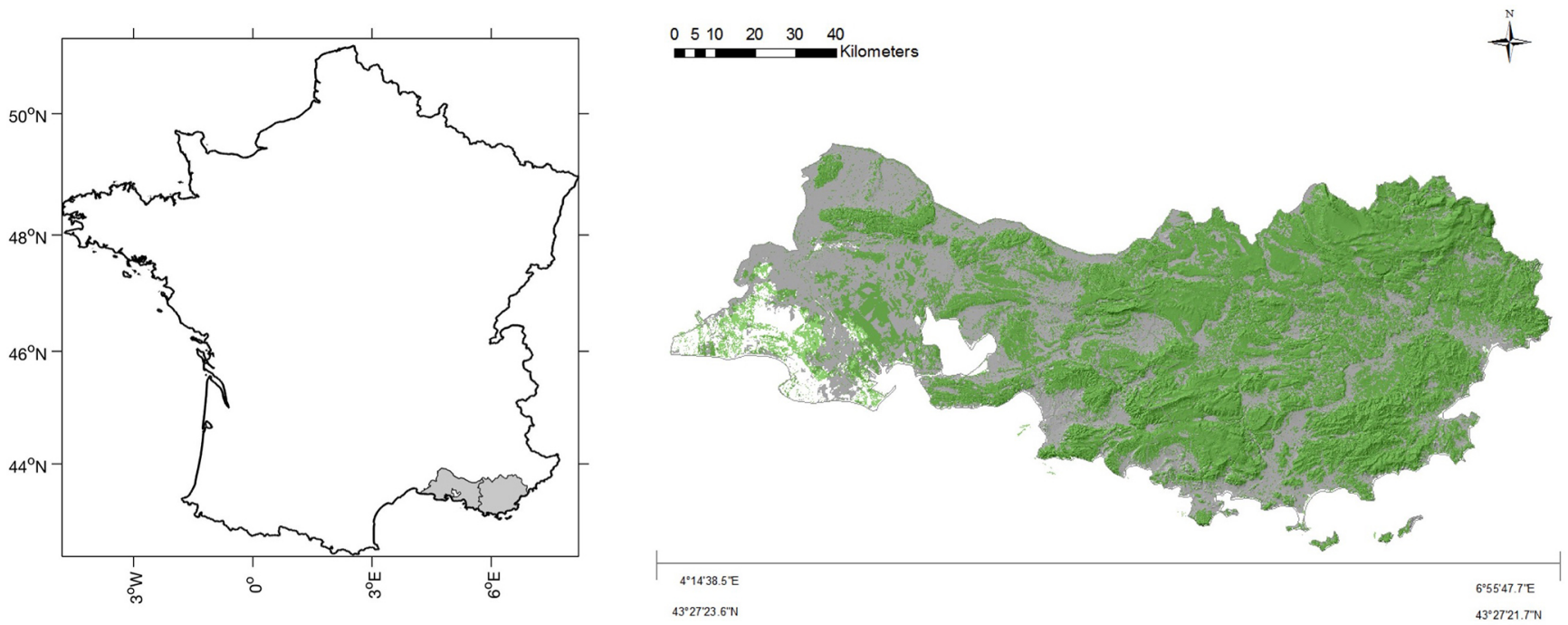

Figure 1. Map of the study area. The boundary between the western and the eastern regions is also indicated. Forested systems in green were extracted from the "BD Forêt 2014" of the National Geographic Institute (https://www.geoportail.gouv.fr).

these gridded data provide neither the fire perimeter needed to assess reburns nor the temporal length needed to assess return periods in large fires. Here, we used the georeferenced fire perimeter database compiled by the Office National des Forêts (ONF) and Directions Départementales des Territoires et de la Mer (DDTM Bouches du Rhône and Var) available from 1961 to 2017 in the western part and from 1958 to 2016 in the eastern part of the study area. Fire perimeters were derived from aerial photography and remote sensing (the latter since 2016) and confirmed by ground truth targeting mostly fires larger than 10 ha in the earliest period. Approximate perimeters of older fire events (i.e., before 1990) have been corrected using aerial photos and Landsat satellite images when available (i.e., a more accurate delineation of fire perimeter adjustment was performed) (Faivre, 2011).

We focused on large fires $\geq 100$ ha (hereafter LFs), representing only $28 \%$ of the total number of fires $\geq 1$ ha $(N=$ 1277) but accounting for $94 \%$ of the total burned area. This detection threshold is within the range of large fire thresholds used in previous works in the French Mediterranean ranging from 30 ha (Ruffault and Mouillot, 2017) to 250 ha (Ruffault et al., 2017).

\subsection{Climate and land cover data}

We computed the daily Fire Weather Index (FWI) from the Canadian Forest Fire Weather Index system using daily surface meteorological variables at an $8 \mathrm{~km}$ spatial resolution from the quality-controlled SAFRAN dataset providing maximum temperature, minimum relative humidity, precipitation and wind speed over France from 1959 to 2017 (Vidal et al., 2010a, b, 2012). The FWI computation usually requires noon observations. However, given that SAFRAN is a daily meteorological database, we calculated FWI using maximum temperature and minimum relative humidity as surrogates of noon observations following prior analyses (e.g., Jolly et al., 2015; Abatzoglou et al., 2018). Although the FWI was empirically calibrated for estimating whether atmospheric conditions and fuel moisture content are prone to wildfire development in Canada (Van Wagner, 1987), the FWI has already proven useful to track large fires in Mediterranean regions (Dimitrakopoulos et al., 2011) including the French Mediterranean (Barbero et al., 2019). Grid cells of the FWI lying within the study area were first averaged across the June-September season and then averaged across all latitudes spanning the region of interest to form a longitudinal cross section of mean summer FWI conditions.

We extracted fuel cover data from the "BD Forêt 2014" of the National Geographic Institute (https://www.geoportail. gouv.fr) and regridded the data onto an $8 \mathrm{~km}$ spatial grid. The percentage of land area covered by forest was computed across all latitudes spanning the region of interest to form a longitudinal cross section as described above.

\subsection{Spatial analyses}

Based on a sequence of 58 layers of annual large fire scars covering the 1958-2017 period, the following fire attributes were extracted: (i) fire recurrence or the number of fires that occurred at the same location over the period studied and (ii) time since the last fire.

Comparisons of means in burned areas due to LFs were performed using a nonparametric Mann-Whitney test, and a $\chi^{2}$ test was used to test the difference in number of LFs between the two parts of the study area. Analyses of variance (ANOVAs) were used to test the influence of the age class on the number and the area burned by LFs (for the latter, data were log-transformed), and comparison of medians (Mann- 


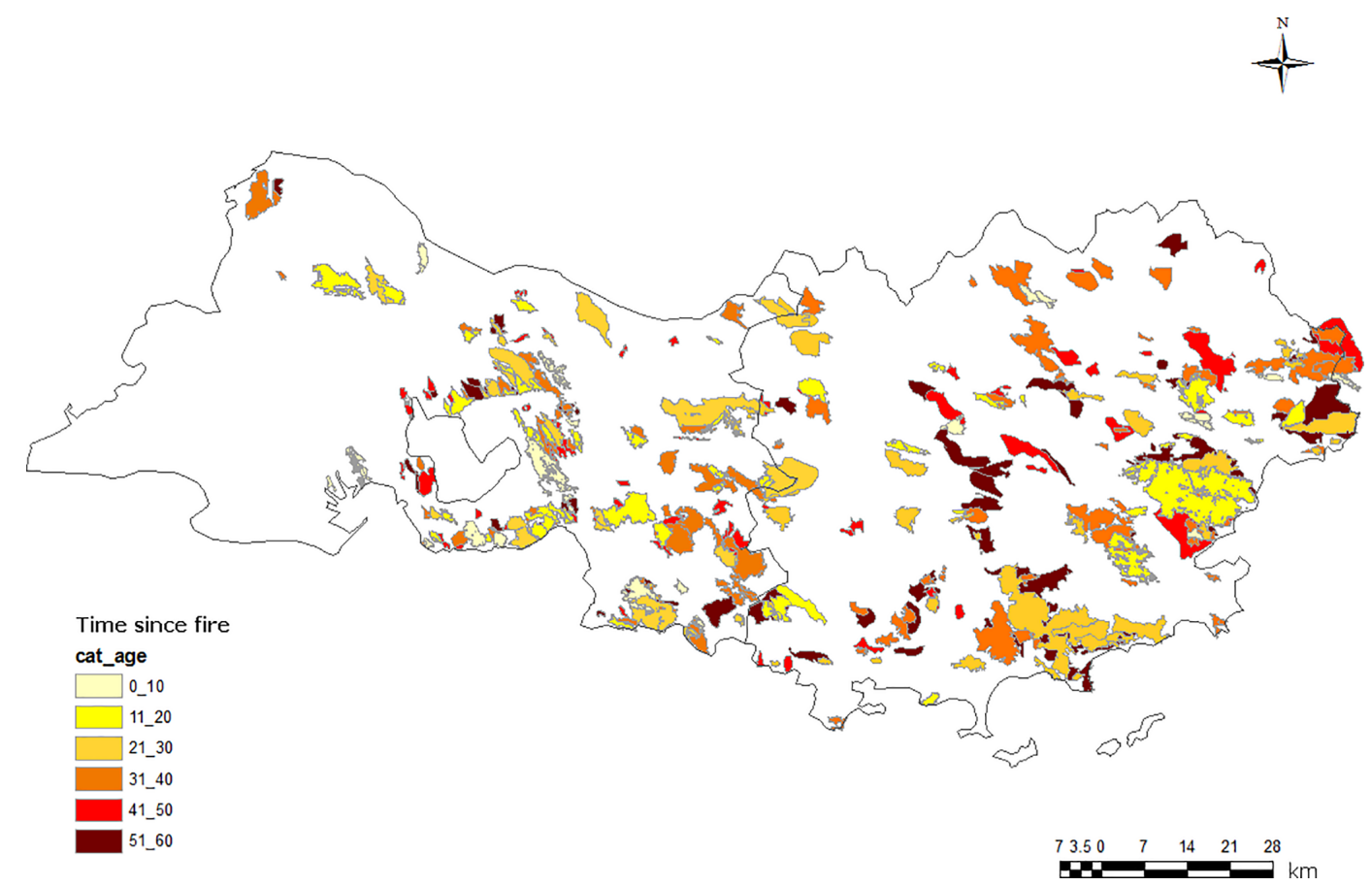

Figure 2. Time since the last LF (cat_age in years).

Whitney test) was used to compare the area burned by the recurrent fires in the west to that in the east.

\subsection{Temporal analyses}

Monotonic trends in LF frequency and in burned area due to LFs were assessed using the nonparametric Mann-Kendall test (Kendall, 1975), and a change point detection test (standard normal homogeneity test, SNHT; Alexandersson and Moberg, 1997) was used to identify potential abrupt changes in the time series.

We estimated annual maximum burned area (AMBA) return levels in the eastern and western parts of the study area using the so-called block (here 1 year) maxima approach. We extracted the AMBA in both areas and selected the type of distribution that best fitted both series using the Akaike information criteria (AIC). In both areas, the gamma distribution was found to best describe the AMBA series. Using this distribution, the inverse cumulative distribution was calculated, allowing the determination of the theoretical quantiles from which we derived the return levels (AMBA) associated with different return periods ranging from 5 to 100 years. Asymmetric confidence intervals were calculated using a resampling approach. This approach consists in creating new sub-samples from the original sample $(75 \%$ of the original sample is extracted at random) using a bootstrapping process with replacement and then estimating a return level for each of the resampled data $(N=1000)$. The resulting empirical distribution can then be used to derive the $95 \%$ confidence intervals from the resulting collection of estimates.

\section{Results}

\subsection{Spatial distribution of large fires and reburned areas}

In total, 353 LFs were recorded in the region (194 in the western part and 159 in the eastern part; $\mathrm{Chi} 2=123.7$ and $p<0.0001$ ) with, however, a higher burned area in the east nearly doubling the area burned in the west (respectively 199404 and 112043 ha representing 3379.7 and 1965.6 ha burned per year; $\mathrm{W}=19306.5$ and $p<0.0001$; Table 1). LFs were responsible for most of the total burned area in the east $(97 \%)$ as well as in the west $(87 \%)$.

Regarding the LF age distribution (Fig. 2), the most frequent LFs belonged to the 31-40-year class resulting in the most LF-prone decade (ANOVA, $p<0.0001$ ), and the mean largest area was burned during the 21-30- and 51-60year classes (1365.5 and 1465.12 ha, respectively; ANOVA, $p<0.0001)$. In the east, recent LFs were mainly located on the coast while the age distribution was more homogeneous in the western part. Notice that most LF growths were in the main wind direction blowing from the northwest.

A total surface area of 311447 was burned during the period studied, of which $21 \%$ occurred on a surface that already burned in the past (Fig. 3), due to multiple overlaps in burned areas by recurrent fires (i.e., LF occurrence on the same surface). LF reburns occurred up to six times in the east but represented only a small part of the recurrence $(0.3 \%$; Table 2). One to two reburns were the most frequent patterns in the western part of the study area $(39.4 \%$ and $39.9 \%$ of 


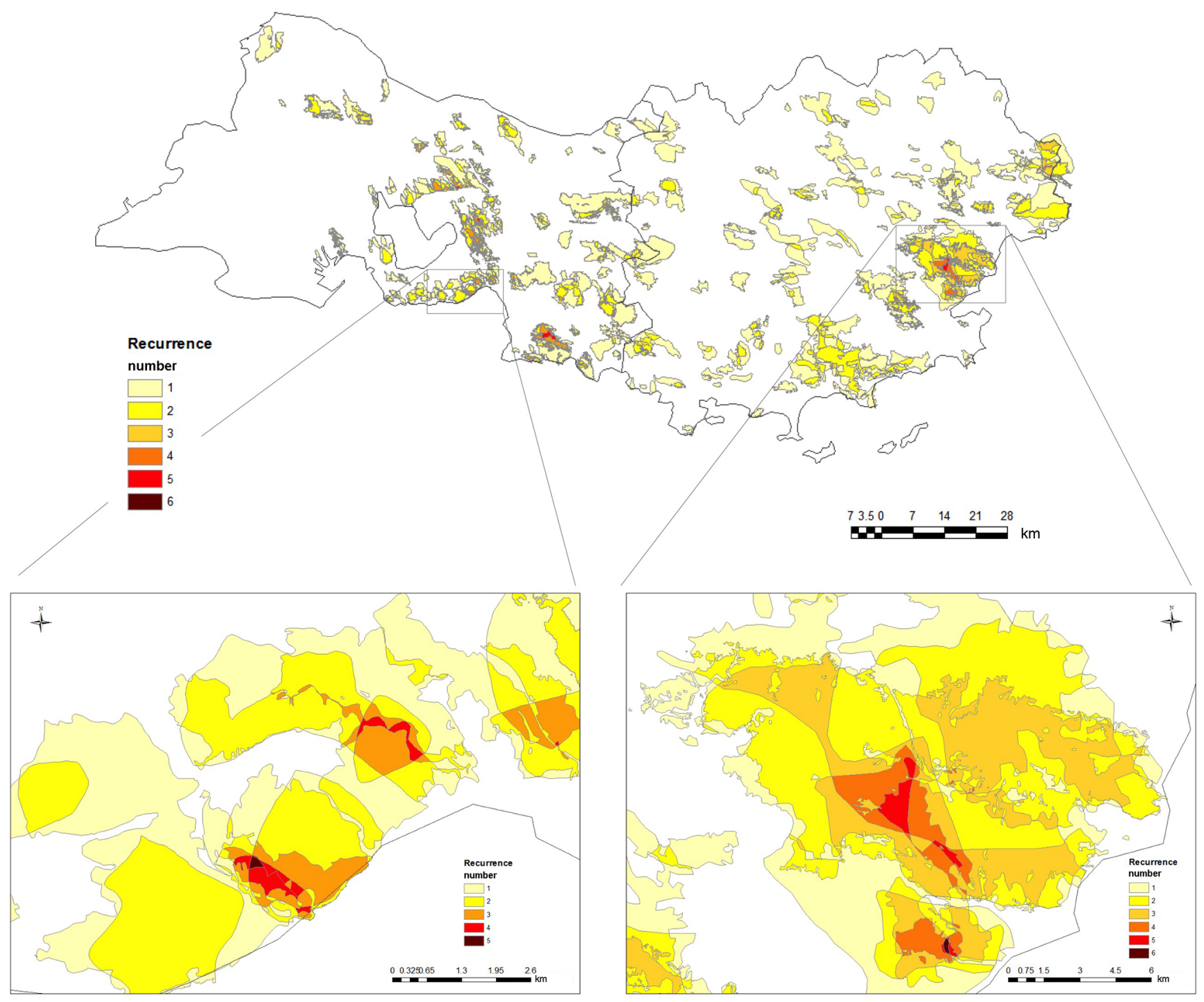

Figure 3. Fire recurrence in the 1961-2017 and 1958-2016 periods in the western and eastern parts, respectively.

Table 1. Statistics on fires ( $\geq 1 \mathrm{ha})$ and LFs ( $\geq 100 \mathrm{ha})$.

\begin{tabular}{lrrrrrrr}
\hline Study area & $\begin{array}{r}\text { Total number } \\
\text { of fires }\end{array}$ & $\begin{array}{r}\text { Total burned } \\
\text { area (ha) }\end{array}$ & Number of LFs: & $\%$ & $\begin{array}{r}\text { Area burned by } \\
\text { LFs (ha) }\end{array}$ & $\begin{array}{r}\text { Record length } \\
\text { (years) }\end{array}$ \\
\hline West & 975 & 128196 & 194 & 20 & 112043 & 87 & 57 \\
East & 302 & 204535 & 159 & 52 & 199404 & 97 & 59 \\
\hline Total & 1277 & 332731 & 353 & 28 & 311447 & 94 &
\end{tabular}

the recurrence, respectively; Table 2) while in the east, most reburns occurred only once $(46.3 \%)$. The surface impacted by only one LF represented $74.5 \%$ and $71.2 \%$ of the total area burned by LFs in the west and the east, respectively (Table 2), and the resulting median LF extent was significantly larger in the east than in the west (668.5 vs. 346.8 ha, respectively; comparison of medians, $p<0.0001$ ).

\subsection{Longitudinal contrast in large fire extent}

The mean LF extent varied along a longitudinal gradient, increasing from the west to the east (Fig. 4a, left axis). This signal contrasts with the mean summer FWI gradient decreasing towards the east but is consistent with the sharp increase in biomass towards the east (Fig. 4b). When nor- 
Table 2. Percentages of burned area (relative to the total burned area) affected by recurrent LFs and percentages of recurrence relative to the $\mathrm{LF}$ frequency (when number $=1, \mathrm{LF}$ is considered non-recurring).

\begin{tabular}{lrr|rr}
\hline & \multicolumn{2}{c|}{ Western part } & \multicolumn{2}{c}{ Eastern part } \\
\cline { 2 - 5 } $\begin{array}{l}\text { Number of LFs } \\
\text { in same }\end{array}$ & $\begin{array}{r}\text { Area burned } \\
\text { by recurrent }\end{array}$ & Frequency & $\begin{array}{r}\text { Area burned } \\
\text { by recurrent }\end{array}$ & Frequency \\
location & LFs & & LFs \\
\hline 1 & $74.5 \%$ & $39.4 \%$ & $71.2 \%$ & $46.3 \%$ \\
2 & $20.3 \%$ & $39.9 \%$ & $22.3 \%$ & $34.7 \%$ \\
3 & $4.5 \%$ & $16.6 \%$ & $5.5 \%$ & $13.1 \%$ \\
4 & $0.7 \%$ & $3.9 \%$ & $0.8 \%$ & $4.1 \%$ \\
5 & $0.005 \%$ & $0.2 \%$ & $0.2 \%$ & $1.5 \%$ \\
6 & - & - & $0.008 \%$ & $0.3 \%$ \\
\hline
\end{tabular}

malizing by the biomass area (Fig. 4a, right axis), the mean LF extent remains stable throughout the longitudinal gradient, except at the eastern edge of the study area, where a sharp increase in LF extent per biomass surface unit was evident. This may be indicative of a stronger fuel connectivity at the eastern edge, regardless of absolute biomass surface available to burn. Overall, these results suggest that LF spread is not limited by climate conditions across the region but strongly fuel-limited in the west, due to landscape fragmentation and the high proportion of WUI (15\%). Indeed, the landscape has undergone substantial transformation with time in the western part, contributing to reduce fuel cover and thereby the potential for fire spread. This highlights the role of fuel quantity and continuity in fire spread as shown in previous research (Hargrove et al., 2000; Finney et al., 2007) and the need to include fuel cover in future projections of fire activity.

\subsection{Long-term trends in large fires}

A significant decline in annual LF frequency alongside area burned by LF was found across the region according to a Man-Kendall test (Fig. 5). This overall decline is consistent with a significant change point in both LF metrics in 1991 as shown in previous findings (Fox et al., 2015; Ruffault and Mouillot, 2015). This signal was especially evident in the eastern part (Fig. 5c) while neither a change point nor a significant trend $(p>0.05)$ was detected in the western part for both LF metrics (Fig. 5b). We then examined how interannual correlations between mean June-September FWI and LF activity have changed over time across both regions (Fig. 5d). Higher correlations prevailed in the western part throughout the period but the relationships strongly weakened with time in both regions in agreement with previous findings (Ruffault and Mouillot, 2015), passing below significance levels across recent years.

Figure 6 shows the AMBA in each part of the study area (panel a) as well as the gamma distribution models that were found as the best fit to the data (panels c, d). Estimates of AMBA return intervals show that a $\mathrm{LF}>4000$ ha occurs on
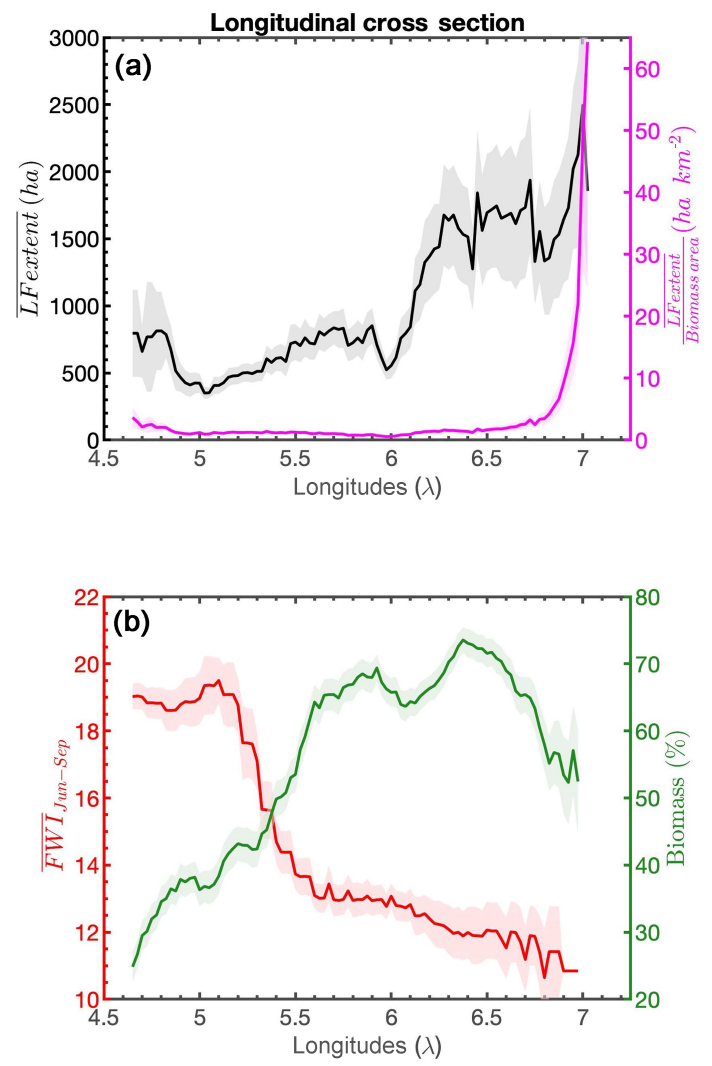

Figure 4. (a) Longitudinal cross section of mean LF extent (ha) computed over $30 \mathrm{~km}$ sliding windows (in black). The magenta line indicates the mean LF extent normalized by the biomass area (expressed in square kilometers). The $95 \%$ confidence intervals were estimated using a bootstrapping approach. (b) Same as (a) but for mean June-September FWI (in red) and the percent of biomass (in green). 

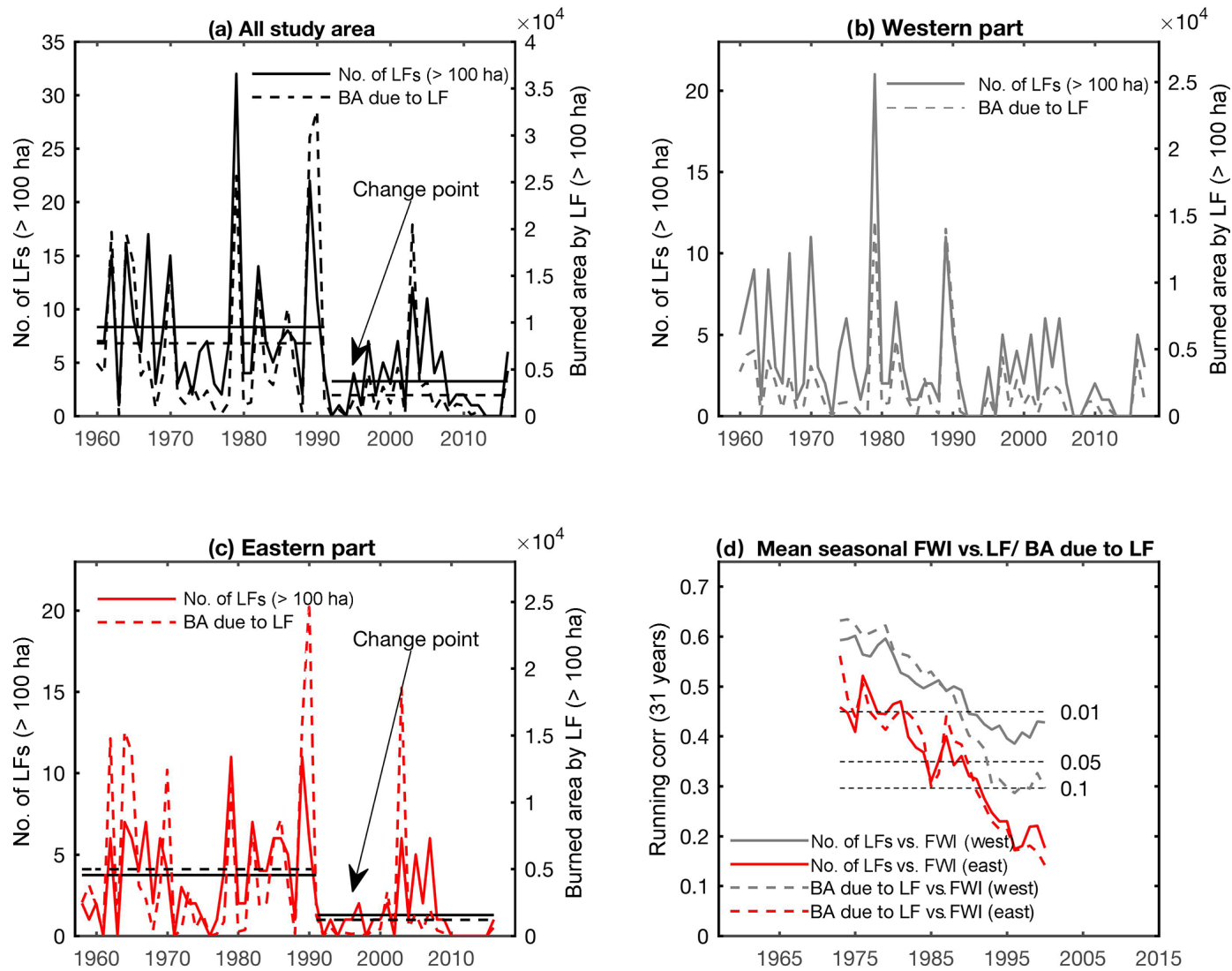

Figure 5. (a) Annual number of LFs (solid line, left axis) and area burned by LFs (dashed lines, right axis) across the region. Significant change points at the $5 \%$ confidence level according to a standard normal homogeneity test (SNHT) in both metrics are indicated. Horizontal lines indicate the overall mean observed before and after the change point. (b) Same as (a) but for the western part. (c) Same as (a) but for the eastern part. (d) Sliding correlations on 31-year windows between mean June-September FWI and annual LF frequency (solid lines) and annual burned area due to LFs (dashed lines) in the western (gray) and eastern parts (red). The horizontal dashed lines indicate different significance levels of the Pearson correlations. Correlations are indicated for the middle of the sliding windows.

average every 7 years in the eastern part and every 55 years in the western part (Fig. 6b), supporting results of Fig. 4 indicating an overall increase in LF extent eastwards.

\section{Discussion}

Improving our understanding of large fire activity is of utmost importance to fire prevention and management to mitigate their impacts. Here, we presented a comprehensive analysis of spatial and temporal patterns of LFs in the French Mediterranean. To our knowledge, the fire database compiled and analyzed in this framework provides, for the first time, a detailed description of LFs recorded on georeferenced long time series.

\subsection{Spatial distribution of large fires and reburned areas}

In total, $21 \%$ of the burned area occurred on a surface that already burned in the past due to multiple overlaps in burned areas by recurrent fires (up to six times in the east). These areas of higher recurrence could induce a loss of resilience of the forest types such as Pinus halepensis stands with an increase in the number of fires and/or a decrease in the time since fire (Eugenio et al., 2006). Results showed that there was a strong spatial variation in LFs according to the time since fire, with clusters of recent LFs along the coast (where the recurrence was the highest) and more ancient LFs in the central and northern part of the eastern area where the tourist pressure is lower. Most of these fires, which occurred more than 30 years ago, were actually escaped prescribed fires during the cool season (Yvon Duché, personal communication, 2019). In contrast, LFs were homogeneously distributed in the west, regardless of their age.

We found that the return level was higher in the eastern part of the study area although LFs were more frequent in the west. These contrasted regional return levels may provide critical and useful information for risk assessment and local decision-making. Indeed, LF $>4000$ ha may occur within 7 years in the east compared with 55 years in the west. In other 

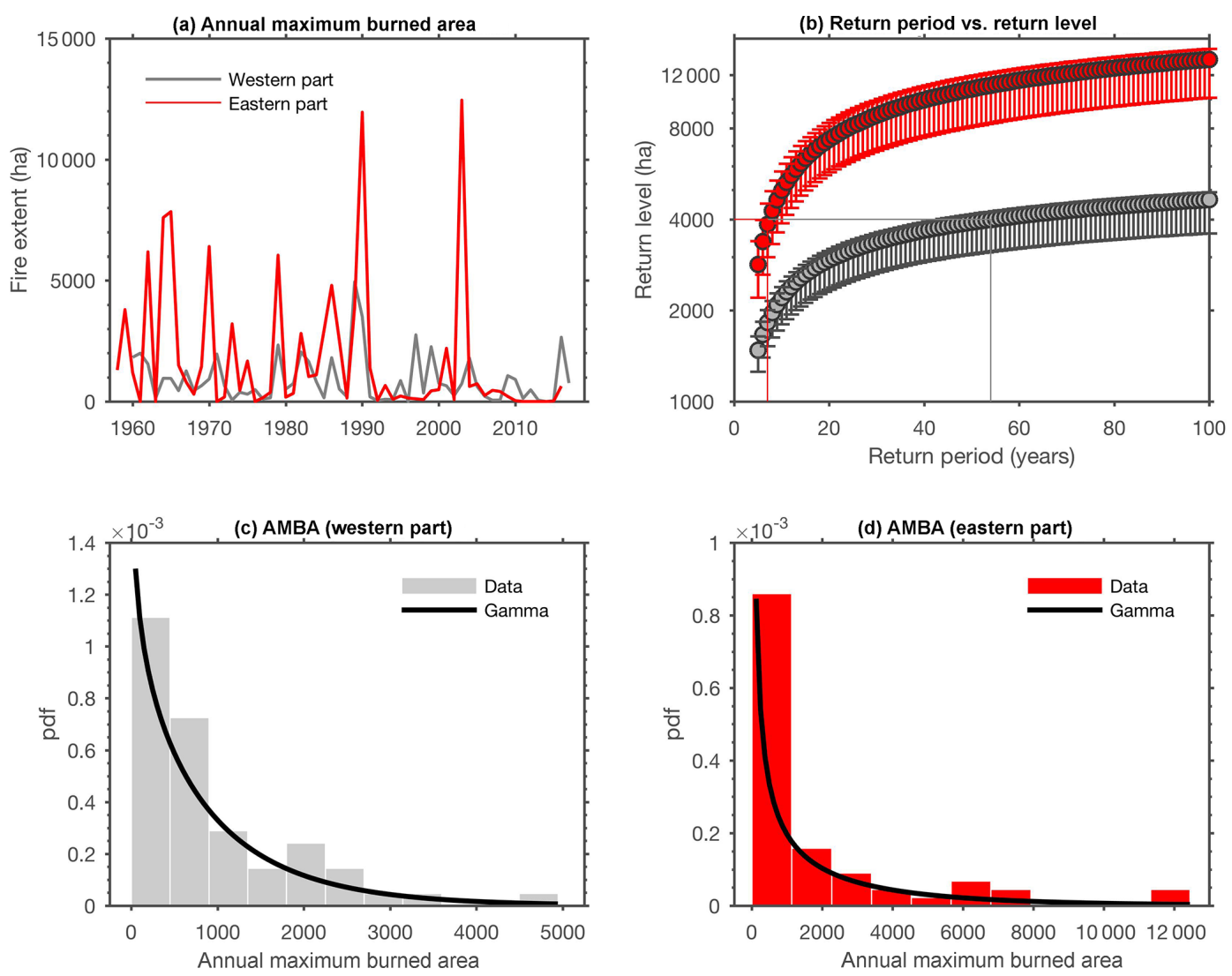

Figure 6. (a) Time series of the annual maximum burned area (AMBA) in the western part (in gray) and in the eastern part (in red). (b) Return levels in AMBA in the western part (in gray) and in the eastern part (in red) for different return periods ranging from 5 to 100 years. The $95 \%$ confidence intervals were estimated using a bootstrapping approach. (c) Distribution of AMBA in the western part (bars) with the gamma distribution (black line) that was found to best describe the data. (d) Same as (c) but for the eastern part.

words, LFs are less probable in the east where fire ignitions are more limited but when an ignition does occur, the fire is likely to spread over larger areas. This longitudinal gradient is likely due to the variation in landscape fragmentation. Indeed, the western area presents a mosaic of wildlands interspersed with agricultural areas and WUIs, LFs being thereby concentrated in natural spaces less extended than in the eastern part where large forested massifs mostly located on the coast allowed fire spread. By contrast, LFs were more frequent in the west where population density, the proportion of WUIs, and infrastructures (railroads and roads) are the highest, as shown in previous works (Keane et al., 2008; La Puma, 2012; Alexandre et al., 2016; Nagy et al., 2018). It should be noted that return levels were estimated here under the assumption of a stationary context. Yet, the new fire policy that took place in the 1990s has been shown to reduce these return levels, albeit its effects on the largest fires were rather limited (Evin et al., 2018). Indeed, our estimates of 50-year return levels in the eastern area lie within the confidence intervals of those observed in Evin et al. (2018) before and after the new fire policy. However, return levels in the west were much lower than those reported in Evin et al. (2018) across a larger region, highlighting the sensitivity of return levels to the spatial aggregation level of the data.

Some recent studies across Euro-Mediterranean countries emphasized that large fire preferentially occurred under specific synoptic patterns associated with high temperature (Pereira et al., 2005; Trigo et al., 2016; Hernandez et al., 2015). In southern France, large fires were also facilitated by wind events blowing from northwest (Ruffault and Mouillot, 2015, 2017). The shapes of LFs which were more elongated in the wind direction in the western part support the results of Ruffault et al. (2018), pinpointing that the main wind-driven large fires that had occurred in 2016 were located in the western part while the main heat-driven large fires that occurred in 2003 were located in the east of the area. Taking into account other metrics describing the LF patch complexity (e.g., azimuthal angle or shape index) as in Laurent et al. (2018) could allow the derivation of additional information on the role of wind in their geometry or in the fraction of LFs driven by wind. 


\subsection{Long-term trends in large fires}

The overall reduction in both LF frequency and burned area observed over the last 6 decades is in agreement with previous works that highlighted a decrease in fire activity across parts of southern Europe in response to an increased effort in fire suppression (Turco et al., 2016), taking place in the early 1990s in the French Mediterranean (Ruffault and Mouillot, 2015; Fox et al., 2015; Curt and Fréjaville, 2018). Indeed, the region was highly impacted by fires during the 19701990 period and developed a thorough fire suppression and prevention system in the beginning of the 1990s, allocating more means for fire management that allowed faster reactivity in case of fire start (the strategy became extinguishing the fires at their initial stage by massive attack to prevent their spread). The decrease in both LF frequency and burned area since 1991, especially evident in the eastern part of the region, is likely due to this change in firefighting policy and fire prevention regulations (fire suppression could be more intense in the east as fires were historically larger in that region).

Climate projections suggest that atmospheric conditions conducive to large fire will increase in the future. Indeed, the warming and drying trends projected in southern Europe are expected to facilitate fire spread (Turco et al., 2018), at least where fuel and ignitions are not limiting. This trend towards more extreme fire weather conditions is likely to overcome prevention efforts in the French Mediterranean (Lahaye et al., 2018), a region where expanding forests (Abadie et al., 2018) are increasing fuel loading and may offer opportunities for future fire spread.

\section{Conclusions}

This work, based on long-term georeferenced fire time series (1958-2017), analyzed both spatial and temporal variations in LFs throughout one of the most impacted areas of the French Mediterranean. On the whole, $21 \%$ of the total area burned by LFs occurred on a surface that had already burned in the past, the region being impacted in some locations up to six times by recurrent LFs (coastal areas of the eastern part of the study area). LFs were less frequent in the eastern part but larger than LFs occurring in the west. This longitudinal gradient in LF extent, featuring a shorter time of occurrence between LFs in the east with respect to the west, contrasts with what we would expect from mean fire weather conditions strongly decreasing eastwards but is consistent with larger fuel cover in the east. Indeed, fuel continuity in the east allows fire to grow large and to reach on average 4000 ha every 7 years, a spatial extent in burned area observed only every 50 years in the west.

An abrupt decline in LF was evident across the eastern part in the early 1990s, mostly due to a change in fire management policy thereby contributing to the weakening of the climate-fire relationship. However, despite large means allocated to fire suppression, large fire outbreak is still possible in the French Mediterranean (such as in 2003 or 2016), as extreme weather conditions can overwhelm fire suppression efforts (Fernandes et al., 2016; Lahaye et al., 2018). A better knowledge of LF drivers is necessary to strengthen fire prevention by providing valuable information on priority areas where LFs are more likely to occur.

Data availability. The data are property of the State: Directions Départementale des Territoires et de la Mer du Var (2019, http://www.var.gouv.fr/) and Directions Départementales des Territoires et de la Mer des Bouches du Rhône (2019, http://www.bouches-du-rhone.gouv.fr/ Services-de-1-Etat/Les-directions-departementales-DD/

La-direction-departementale-des-territoires-et-de-la-mer-DDTM). These data are available only upon request to willy.martin@var.gouv.fr and gael.bettinelli@bouches-du-rhone.gouv.fr.

Competing interests. The authors declare that they have no conflict of interest.

Special issue statement. This article is part of the special issue "Spatial and temporal patterns of wildfires: models, theory, and reality". It is a result of the conference EGU 2017, Vienna, Austria, 23-28 April 2017.

Acknowledgements. The authors wish to thank Adeline Bellet and Denis Morge for preprocessing the data with ArcGIS. The authors also sincerely thank Aimee Mac Cormack for English revision of a previous version of the paper. The authors also thank the two anonymous reviewers for their constructive comments and suggestions that helped improved the quality of the paper.

Review statement. This paper was edited by Ricardo Trigo and reviewed by two anonymous referees.

\section{References}

Abadie, J., Dupouey, J.-L., Avon, C., Rochel, X., Tatoni, T. and Bergès, L.: Forest recovery since 1860 in a Mediterranean region: drivers and implications for land use and land cover spatial distribution, Landscape Ecol., 33, 289-305, https://doi.org/10.1007/s10980-017-0601-0, 2018.

Abatzoglou, J. T. and Williams, A. P.: Impact of anthropogenic climate change on wildfire across western US forests, P. Natl. Acad. Sci. USA, 113, 11770-11775, 2016.

Abatzoglou, J. T., Barbero, R., and Nauslar, N. J.: Diagnosing Santa Ana winds in southern California with synoptic-scale analysis, Weather Forecast., 28, 704-710, https://doi.org/10.1175/WAFD-13-00002.1, 2013. 
Abatzoglou, J. T., Williams, A. P., Boschetti, L., Zubkova, M., and Kolden, C. A.: Global patterns of interannual climate-fire relationships, Glob. Change Biol., 24, 5164-5175, 2018.

Alexandersson, H. and Moberg, A.: Homogenization of Swedish temperature data. Part I: Homogeneity test for linear trends, Int. J. Climatol., 17, 25-34, 1997.

Alexandre, P. M., Stewart, S. I., Keuler, N. S., Clayton, M. K., Mockrin, M. H., Bar-Massada, A., Syphard, A. D., and Radeloff, V. C.: Factors related to building loss due to wildfires in the conterminous United States, Ecol. Appl., 26, 2323-2338, 2016.

Barbero, R., Abatzoglou, J. T., Steel, E. A., and Larkin, N. K.: Modeling very large-fire occurrences over the continental United States from weather and climate forcing, Environ. Res. Lett., 9, 124009, 2014.

Barbero, R., Abatzoglou, J. T., Kolden, C., Hegewisch, K., Larkin, N. K., and Podschwit, H.: Multi-scalar influence of weather and climate on very large-fires in the eastern United States, Int. J. Climatol., 35, 2180-2186, https://doi.org/10.1002/joc.4090, 2015a.

Barbero, R., Abatzoglou, J. T., Larkin, N. K., Kolden, C. A., and Stocks, B.: Climate change presents increased potential for very LF in the contiguous United States, Int. J. Wildland Fire, 24, 892-899, 2015b.

Barbero, R., Curt, T., Ganteaume, A., Maillé, E., Jappiot, M., and Bellet, A.: Simulating the effects of weather and climate on large wildfires in France, Nat. Hazards Earth Syst. Sci., 19, 441-454, https://doi.org/10.5194/nhess-19-441-2019, 2019.

Blanchi, R., Leonard, J., Haynes, K., Opie, K., James, M. and Dimer de Oliveira, F.: Environmental circumstances surrounding bushfire fatalities in Australia 1901-2011, Environ. Sci. Policy, 37, 192-203, 2014.

Bradstock, R. A., Cohn, J. S., Gill, A. M., Bedward, M., and Lucas, C.: Prediction of the probability of LF in the Sydney region of south-eastern Australia using fire weather, Int. J. Wildland Fire, 18, 932-943, 2009.

Curt, T. and Fréjaville, T.: Wildfire Policy in Mediterranean France: How Far is it Efficient and Sustainable?, Risk Anal., 38, 472488, https://doi.org/10.1111/risa.12855, 2018.

Dennison, P. E., Brewer, S. C., Arnold, J. D., and Moritz, M. A.: Large wildfire trends in the western United States, 1984-2011, Geophys. Res. Lett., 41, 2928-293, 2014.

Dimitrakopoulos, A. P., Bemmerzouk, A. M., and Mitsopoulos, I. D.: Evaluation of the Canadian fire weather index system in an eastern Mediterranean environment, Meteorol. Appl., 18, 83-93, https://doi.org/10.1002/met.214, 2011.

Direction Départementale des territoires et de la Mer des Bouches du Rhône: available at: http://www.bouches-du-rhone. gouv.fr/Services-de-1-Etat/Les-directions-departementales-DD/ La-direction-departementale-des-territoires-et-de-la-mer-DDTM/, last access: 18 January 2019.

Direction Départementale des territoires et de la Mer du Var: available at: http://www.var.gouv.fr/, last access: 13 May 2019.

Duane, A., Piqué, M., Castellnou, M., and Brotons, L.: Predictive modelling of fire occurrences fromdifferent fire spread patterns in Mediterranean landscapes, Int. J. Wildland Fire, 24, 407-418, https://doi.org/10.1071/WF14040, 2015.

Eugenio, M., Verkaik, I., Lloret, F., and Espelta, J. M.: Recruitment and growth decline in Pinus halepensis populations after recurrent wildfires in Catalonia (NE Iberian Peninsula), Forest Ecol. Manag., 231, 47-54, 2006.
Evin, G., Curt, T., and Eckert, N.: Has fire policy decreased the return period of the largest wildfire events in France? A Bayesian assessment based on extreme value theory, Nat. Hazards Earth Syst. Sci., 18, 2641-2651, https://doi.org/10.5194/nhess-182641-2018, 2018

Faivre, N.: Which pyrodiversity for what biodiversity? A multiscale comparative study of two Mediterranean ecosystems, PhD Dissertation, Aix-Marseille University, France, 2011.

Fernandes, P. M., Pacheco, A. P., Almeida, R., and Claro, J.: The role of fire suppression force in limiting the spread of extremely large forest fires in Portugal, Eur. J. For. Res., 135, 253-262, https://doi.org/10.1007/S10342-015-0933-8, 2016.

Finney, M. A., Seli, R. C., McHugh, C., Ager, A. A., Bahro, B., and Agee, J. K.: Simulation of long-term landscape level fuel treatment effects on large wildfires, Int. J. Wildland Fire, 16, 712727, 2007.

Flannigan, M. D., Krawchuk, M. A., de Groot, W. J., Wotton, B. M., and Gowman, L. M.: Implications of changing climate for global wildland fire, Int. J. Wildland Fire, 18, 483-507, 2009.

Fox, D. M., Martin, N., Carrega, P., Andrieu, J., Adnès, C., Emsellem, K., Ganga, O., Moebius, F., Tortorollo, N., and Fox, E. A.: Increases in fire risk due to warmer summer temperatures and wildland urban interface changes do not necessarily lead to more fires, Appl. Geogr., 56, 1-12, https://doi.org/10.1016/j.apgeog.2014.10.001, 2015.

Fréjaville, T. and Curt, T.: Spatiotemporal patterns of changes in fire regime and climate: defining the pyroclimates of south-eastern France (Mediterranean Basin), Climatic Change, 129, 239-51, 2015.

Fréjaville, T. and Curt, T.: Seasonal changes in the human alteration of fire regimes beyond the climate forcing, Environ. Res. Lett. 12, 035006, https://doi.org/10.1088/1748-9326/AA5D23, 2017.

Ganteaume, A. and Jappiot, M.: What causes LF in Southern France, Forest Ecol. Manag., 294, 76-85, https://doi.org/10.1016/j.foreco.2012.06.055, 2013.

Ganteaume, A. and Guerra, F.: Explaining the spatio-seasonal variation of fires by their causes: The case of southeastern France, Appl. Geogr., 90, 69-81, 2018.

Ganteaume, A. and Long-Fournel, M.: Driving factors of fire density can spatially vary at the local scale in SE France, Int. J. Wildland Fire, 24, 650-664, 2015.

Ganteaume, A., Jappiot, M., Lampin-Maillet, C., Curt, T., and Borgniet, L.: Fuel characterization and effects of wildfire on limestone soils in southeastern France, Forest Ecol. Manag., 258S, S15-S23, 2009.

Ganteaume, A., Camia A., Jappiot M., San Miguel-Ayanz J., LongFournel, M., and Lampin, C.: A Review of the Main Driving Factors of Forest Fire Ignition Over Europe, Environ. Manage., 51, 651-662, 2013.

Hargrove, W. W., Gardner, R. H., Turner, M. G., Romme, W. H., and Despain, D. G.: Simulating fire patterns in heterogeneous landscapes, Ecol. Model., 135, 243-263, 2000.

Hawbaker, T. J., Radeloff, V. C., Stewart, S. I., Hammer, R. B., Keuler, N. S., and Clayton, M. K.: Human and biophysical influences on fire occurrence in the United States, Ecol. Appl., 23, $565-82,2013$.

Hernandez, C., Drobinski, P., and Turquety, S.: How much does weather control fire size and intensity in the 
Mediterranean region?, Ann. Geophys., 33, 931-939, https://doi.org/10.5194/angeo-33-931-2015, 2015.

Jolly, W. M., Cochrane, M. A., Freeborn, P. H., Holden, Z. A., Brown, T. J., Williamson, G. J., and Bowman, D. M. J. S.: Climate-induced variations in global wildfire danger from 1979 to 2013, Nat. Commun., 14, 7537, https://doi.org/10.1038/ncomms8537, 2015.

Keane, R. E., Agee, J. K., Fulé, P., Keeley, J. E., Key, C., Kitchen, S. G., Miller, R., and Schulte, L. A.: Ecological effects of largefires on US landscapes: benefit or catastrophe?, Int. J. Wildland Fire, 17, 696-712, 2008.

Kendall, M. G.: Rank Correlation Methods, 4th ed., Charles Griffin, London, 1975.

Kolden, C. A. and Abatzoglou, J. T.: Spatial Distribution ofWildfires Ignited under Katabatic versus Non-KatabaticWinds in Mediterranean Southern California USA, Fire, 1, 19, https://doi.org/10.3390/fire1020019, 2018.

Lahaye, S., Curt, T., Fréjaville, T., Sharples, J., Paradis, L., and Hély, C.: What are the drivers of dangerous fires in Mediterranean France?, Int. J. Wildland Fire, 27, 155-163, 2018.

La Puma, I. P.: Fire in the pines: A landscape perspective of human-induced ecological change in the pinelands of New Jersey, PhD Dissertation, Rutgers University, New Brunswick, NJ, USA, 2012.

Littell, J. S., McKenzie, D., Peterson, D. L., and Westerling, A. L.: Climate and wildfire area burned in western US ecoprovinces 1916-2003, Ecol. Appl., 19, 1003-1021, 2009.

McKenzie, D., Gedalof, Z., Peterson, D. L., and Mote, P.: Climatic change, wildfire, and conservation, Conserv. Biol., 18, 890-902, 2004

Miller, J. D., Safford, H. D., Crimmins, M., and Thode, A. E.: Quantitative evidence for increasing forest fire severity in the Sierra Nevada and southern Cascade Mountains, California and Nevada, USA, Ecosystems, 12, 16-32, 2009.

Moreira, F., Viedma, O., Arianoutsou, M., Curt, T., Koutsias, N., Rigolot, E., Barbati, A., Corona, P., Vaz, P., Xanthopoulos, G., Mouillot, F., and Bilgili, E.: Landscape-wildfire interactions in southern Europe: implications for landscape management, J. Environ. Manage., 92, 2389-2402, 2011.

Moritz, M. A., Parisien, M.-A., Batllori, E., Krawchuk, M. A., Van Dorn, J., Ganz, D. J., and Hayhoe, K.: Climate change and disruptions to global fire activity, Ecosphere, 3, 1-22, 2012.

Mouillot, F. and Field, C.B.: Fire history and the global carbon budget: a 1 degrees $\times 1$ degrees fire history reconstruction for the 20th century, Glob. Change Biol., 11, 398-420, 2005.

Nagy, R. C., Fusco, E., Bradley, B., Abatzoglou, J. T., and Balch, J.: Human-Related Ignitions Increase the Number of Large Wildfires across U.S. Ecoregions, Fire, 1, 4, https://doi.org/10.3390/fire1010004, 2018.

Pausas, J. G. and Fernández-Muñoz, S.: Fire regime changes in the Western Mediterranean Basin: From fuel-limited to droughtdriven fire regime, Climatic Change, 110, 215-226, 2012.

Pereira, M. G., Trigo, R. M., da Camara, C. C., Pereira, J., and Leite, S. M.: Synoptic patterns associated with large summer forest fires in Portugal, Agr. Forest Meteorol., 129, 11-25, 2005.

Radeloff, V. C., Helmers, D. P., Kramer, H. A., Mockrin, M. H., Alexandre, P. M., Bar-Massada, A., Butsic, V., Hawbaker, T. J., Martinuzzi, S., Syphard, A. D., and Stewart, S. I., Rapid growth of the US wildland-urban interface raises wildfire risk, P. Natl. Acad. Sci. USA, 115, 3314-3319, https://doi.org/10.1073/pnas.1718850115, 2018.

Ruffault, J. and Mouillot, F.: How a new fire-suppression policy can abruptly reshape the fire-weather relationship, Ecosphere, 6, 119, https://doi.org/10.1890/ES15-00182.1, 2015.

Ruffault, J. and Mouillot, F.: Contribution of human and biophysical factors to the spatial distribution of forest fire ignitions and large wildfires in a French Mediterranean region, Int. J. Wildland Fire, 26, 498-508, https://doi.org/10.1071/WF16181, 2017.

Ruffault, J., Moron, V., Trigo, R. M., and Curt, T.: Objective identification of multiple large fire climatologies: an application to a Mediterranean ecosystem, Environ. Res. Lett., 11, 75006, https://doi.org/10.1088/1748-9326/11/7/075006, 2016.

Ruffault, J., Moron, V., Trigo, R. M., and Curt, T.: Daily synoptic conditions associated with large fire occurrence in Mediterranean France: evidence for a wind-driven fire regime, Int. J. Climatol., 37, 524-533, https://doi.org/10.1002/joc.4680, 2017.

Ruffault, J., Curt, T., Martin-StPaul, N. K., Moron, V., and Trigo, R. M.: Extreme wildfire events are linked to global-changetype droughts in the northern Mediterranean, Nat. Hazards Earth Syst. Sci., 18, 847-856, https://doi.org/10.5194/nhess-18-8472018, 2018.

San Miguel-Ayanz, J., Moreno, J. M., and Camia, A.: Analysis of LF in European Mediterranean landscapes: Lessons learned and perspectives, Forest Ecol. Manag., 294, 11-22, 2013.

Shvidenko, A. Z. and Nilsson, S.: Extent, distribution, and ecological role of fire in Russian forests, in: Climate Change, and Carbon Cycling in the Boreal Forest, Ecological Studies, 138, edited by: Kasischke, E. S. and Stocks, B. J., Springer-Verlag, Berlin, 132-150, 2000.

Stephens, S. L., Burrows, N., Buyantuyev, A., Gray, R. W., Keane, R. E., Kubian, R., Liu, S., Seijo, F., Shu, L., and Tolhurst, K.G.: Temperate and boreal forest mega-fires: Characteristics and challenges, Front. Ecol. Environ., 12, 115-122, 2014.

Stocks, B. J., Mason, J. A., Todd, J. B., Bosch, E. M., Wotton, B. M., Amiro, B. D., Flannigan, M. D., Hirsch, K. G., Logan, K. A., Martell, D. L., and Skinner, W. R.: Large forest fires in Canada, 1959-1997, J. Geophys. Res.-Atmos., 107, FFR 5-1-FFR 5-12, https://doi.org/10.1029/2001JD000484, 2002.

Stavros, E. N., Abatzoglou, J. T., Larkin, N. K., McKenzie, D., and Steel E. A.: Climate and very large wildland fires in the contiguous western USA, Int. J. Wildland Fire, 23, 899-914, https://doi.org/10.1071/WF13169, 2014.

Syphard, A. D. and Keeley, J. E.: Location, timing and extent of wildfire vary by cause of ignition, Int. J. Wildland Fire, 24, 27 36, doi.org/10.1071/WF14024, 2015.

Syphard, A. D., Clarke, K. C., and Franklin, J.: Simulating fire frequency and urban growth in southern California coastal shrublands, Landscape Ecol., 22, 431-445, https://doi.org/10.1007/S10980-006-9025-Y, 2007.

Syphard, A. D., Keeley, J. E., Pfaff, A. H., and Ferschweiler, K.: Human presence diminishes the importance of climate in driving fire activity across the United States, P. Natl. Acad. Sci. USA, 114, 13750-13755, https://doi.org/10.1073/pnas.1713885114, 2017.

Tedim, F., Leone, L., Amraoui, M., Bouillon, C., Coughlan, M. R., Delogu, G. M., Fernandes, P. M., Ferreira, C., McCaffrey, S., McGee, T. K., Parente, J., Paton, D., Pereira, M. G., Ribeiro, L. M., Viegas, D. X., and Xanthopoulos, G.: Defining Extreme 
Wildfire Events: Difficulties, Challenges, and Impacts, Fire, 1, 9, https://doi.org/10.3390/fire1010009, 2018.

Trigo, R. M., Sousa, P. M., Pereira, M. G., Rasilla, D., and Gouveia, C. M.: Modelling wildfire activity in Iberia with different atmospheric circulation weather types, Int. J. Climatol., 36, 27612778, https://doi.org/10.1002/joc.3749, 2016.

Turco, M., Bedia, J., Di Liberto, F., Fiorucci, P., von Hardenberg, J., Koutsias, N., Llasat, M. C., Xystrakis, F., and Provenzale A.: Decreasing Fires in Mediterranean Europe, PLoS One, 11, e0150663, https://doi.org/10.1371/journal.pone.0150663, 2016.

Turco, M., Rosa-Cánovas, J. J., Bedia, J., Jerez, S., Montávez, J. P., Llasat, M. C., and Provenzale, A.: Exacerbated fires in Mediterranean Europe due to anthropogenic warming projected with nonstationary climate-fire models, Nat. Commun., 9, 3821, https://doi.org/10.1038/s41467-018-06358-z, 2018.

Van Wagner, C. E.: Development and structure of the Canadian forest fire weather index system, Canadian Forestry Service, Forestry Technical Report 35, Ottawa, ON, Canada, available at: https://cfs.nrcan.gc.ca/publications?id=19927 (last access: 1 February 2018), 1987.
Vidal, J.-P., Martin, E., Franchistéguy, L., Baillon, M., and Soubeyroux, J.-M. : A 50-year high-resolution atmospheric reanalysis over France with the Safran system, Int. J. Climatol., 30, 16271644, https://doi.org/10.1002/joc.2003, 2010a.

Vidal, J.-P., Martin, E., Franchistéguy, L., Habets, F., Soubeyroux, J.-M., Blanchard, M., and Baillon, M.: Multilevel and multiscale drought reanalysis over France with the Safran-Isba-Modcou hydrometeorological suite, Hydrol. Earth Syst. Sci., 14, 459-478, https://doi.org/10.5194/hess-14-459-2010, 2010 b.

Vidal, J.-P., Martin, E., Kitova, N., Najac, J., and Soubeyroux, J.M.: Evolution of spatio-temporal drought characteristics: validation, projections and effect of adaptation scenarios, Hydrol. Earth Syst. Sci., 16, 2935-2955, https://doi.org/10.5194/hess-16-29352012, 2012.

Westerling, A. L., Hidalgo, H. G., Cayan, D. R., and Swetnam, T. W.: Warming and earlier spring increase Western US forest wildfire activity, Science, 313, 940-943, 2006. 